\title{
Kemampuan Motorik Kasar Anak melalui Kegiatan Tari Kreasi Baru
}

\section{Y. Puspa Andriani}

RA An-Nihayah Bandung Barat

Bojongranca, Kecamatan Cipongkor, Kabupaten Bandung Barat

Email: iyangpuspaandriani075@gmail.com

\section{Naskah diterima: 26 Juli 2019, direvisi: 09 September 2019, diterbitkan: 27 September 2019}

\section{Abstrak}

Penelitian ini bertujuan untuk mengetahui kemampuan motorik kasar anak melalui kegiatan tari kreasi baru (kelas eksperimen) di RA An-Nihayah Bojongranca Kecamatan Cipongkor Kabupaten Bandung Barat, kemampuan motorik kasar anak melalui kegiatan tari daerah (kelas kontrol) di RA An-Nihayah Bojongranca Kecamatan Cipongkor Kabupaten Bandung Barat, dan perbedaan kemampuan motorik kasar anak melalui kegiatan tari kreasi baru dengan kegiatan tari daerah di RA An-Nihayah Bojongranca Kecamatan Cipongkor Kabupaten Bandung Barat. Metode penelitian ini menggunakan kuasi eksperimen dengan desain penelitian nonequivalent control group desain. Subjek pada penelitian ini adalah anak kelompok B RA An-Nihayah Bojongranca Kecamatan Cipongkor Kabupaten Bandung Barat sebanyak 29 orang. Berdasarkan hasil analisis data, diketahui bahwa hasil penelitian menunjukkan kemampuan motorik kasar anak kelas eksperimen dengan kegiatan tari kreasi baru diperoleh nilai rata-rata pre test sebesar 55 dan post test sebesar 80 . Sedangkan pada kelas kontrol dengan kegiatan tari daerah nilai rata-rata pre test 53 dan post test sebesar 72 . perbandingan kemampuan motorik kasar anak dengan kegiatan tari kreasi baru dan kegiatan tari daerah memiliki perbedaan yang signifikan, hal ini dibuktikan dari hasil uji hipotesis yang menunjukkan nilai $t_{\text {hitung }}=3,416>t_{\text {tabel }}=2,052$ pada taraf signifikansi $5 \%$.

Kata kunci: Anak Usia Dini, Motorik Kasar, Kegiatan Tari.

\begin{abstract}
This study aims to determine the children's gross motor skills through new creative dance activities (experimental class) in RA An-Nihayah Bojongranca Cipongkor District West Bandung Regency, children's gross motor skills through regional dance activities (control class) in $\mathrm{R} A$ An-Nihayah Bojongranca Cipongkor District West Bandung Regency, and the differences in children's gross motor skills
\end{abstract}


through new creative dance activities with regional dance activities in $\mathrm{R} A$ An-Nihayah Bojongranca Cipongkor District West Bandung Regency. This research method uses a quasi experimental research design with a nonequivalent control group design. The subjects in this study were the children of group $B$ $\mathrm{R} A$ An-Nihayah Bojongranca Cipongkor District West Bandung Regency as many as 29 people. Based on the results of data analysis, it is known that the results of the study show that the gross motor skills of the experimental class children with new creative dance activities obtained an average pre test score of 55 and post test of 80 . While in the control class with regional dance activities the average score of pre test 53 and post test of 72. Comparison of children's gross motor skills with new creative dance activities and regional dance activities have a significant difference, this is evidenced from the result of bypothesis testing that shows the value of $t_{\text {arithmetic }}=3,416>t_{\text {table }}=2,052$ at a significance level of $5 \%$.

Keywords: early childhood, rough motoric, dance activities.

\section{Pendahuluan}

Pembelajaran bagi anak usia dini diselenggarakan dalam upaya membantu setiap anak pada rentang usia 0-6 tahun untuk mencapai setiap tugas-tugas perkembangannya secara optimal. Melalui pembelajaran formal, informal dan nonformal, anak-anak diharapkan mampu mengembangkan setiap potensi yang dimilikinya melalui enam aspek, yaitu aspek nilai agama dan moral, kognitif, bahasa, fisik dan motorik, sosial emosional dan seni (Mursyid, 2015: 4).

Pertumbuhan adalah perubahan secara fisiologis sebagai hasil proses pematangan fungsi dalam perjalanan waktu tertentu, sedangkan perkembangan adalah perubahan secara psikologis terhadap anak. Potensi anak mengalami masa peka untuk tumbuh dan kembang secara cepat dan hebat, karena anak usia dini sering disebut dengan istilah golden age atau masa emas (Suhada, 2016: 23).

Masa anak usia dini adalah masa dimana anak belum mengetahui potensi dan cara untuk mengembangkan minat dan bakat yang terdapat dalam dirinya. Dimasa ini anak masih mementingkan dirinya untuk kepentingan individu dalam menjalankan permainan yang mereka lakukan secara bersamaan dalam bersenang-senang. Dengan demikian, orang tua serta pendidik harus berupaya memperhatikan semua aspek pertumbuhan dan perkembangan baik jasmani dan rohani, termasuk perkembangan fisik motoriknya, baik fisik motorik kasar dan fisik motorik halus (Suhada, 2016: 115).

Menurut Decaprio (2013: 18) motorik kasar merupakan gerakan tubuh yang menggunakan otot-otot besar atau sebagian besar otot yang ada dalam tubuh maupun 
seluruh anggota tubuh yang dipengaruhi oleh kematangan diri. Motorik memegang peranan penting bagi anak dalam membantu melewati setiap tahap-tahap perkembangannya. Sedangkan menurut Susanto (2011: 32) kemampuan motorik kasar anak usia dini adalah suatu kemampuan yang membutuhkan koordinasi dengan seluruh bagian tubuh seperti otot tangan, kaki, dan kepala.

Tujuan dari kemampuan motorik kasar pada anak yaitu mampu meningkatkan keterampilan gerak. Kegiatan-kegiatan motorik yang dilakukan di sekolah bertujuan untuk meningkatkan kemampuan gerak pada anak. Anak yang pada awalnya belum mampu mengombinasikan antara tangan dan kaki dapat meningkatkan kemampuan melalui kegiatan motorik. Misalnya, anak yang pada awalnya belum mampu mengombinasikan antara tangan dan kaki secara bersamaan, melalui kegiatan tari kreasi baru dapat distimulasi sehingga anak dapat memiliki kemampuan dalam menggerakkan tangan dan kakinya secara bersamaan (Saputra \& Rudyanto, 2005: 115).

Penelitian ini dilatarbelakangi oleh kemampuan motorik kasar anak kelompok B RA An-Nihayah Bojongranca Kecamatan Cipongkor Kabupaten Bandung Barat yang masih dalam kategori kurang, karena memperoleh nilai rata-rata 59. Hal ini disebabkan karena beberapa anak kurang mampu melakukan gerakan memutar, berjinjit, berdiri di atas satu kaki, mengayun, berjingkrak, dan melakukan gerakan keseimbangan serta gerakan koordinasi. Kondisi tersebut mungkin disebabkan karena metode pembelajaran yang digunakan masih bersifat sederhana. Dalam melakukan pembelajaran, kegiatan tari untuk anak usia dini masih jarang digunakan, hanya digunakan saat pergantian Tahun Ajaran dan guru memilih beberapa anak untuk melakukan kegiatan tari.

Pada penelitian ini gerakan tari yang digunakan bukan tarian yang sudah ada ataupun sudah jadi, dan tidak memerlukan waktu yang sangat singkat untuk mengasah kemampuan motorik kasar yang dapat menstimulus anak dengan baik. Dalam hal ini peneliti mempersiapkan tarian-tarian secara bertahap, kemudian menciptakan gerakan tari dasar yang mudah untuk dilakukan. Penulis menciptakan tarian untuk menarik perhatian anak yang berujung mengembangkan potensi dan imajinasi dalam berkreasi dengan tari kreasi baru. Menurut Caturwati (2008: 165) tari kreasi baru merupakan karya tari yang dihasilkan atas kreativitas individual atau kelompok sebagai karya yang ditata dengan sentuhan atau cita rasa yang baru. Sedangkan menurut Rachmi (2008: 21) tari kreasi baru adalah tarian yang telah mengalami pengembangan atau bertolak dari pola-pola tari yang sudah ada. Menurut Merdekawaty (2010: 18) terdapat beberapa macam tari kreasi baru, 
yaitu ranup lampuan, rampoe aceh, pemulian jame, tarek pukat, limong sikarang, dan rampak dua.

Tujuan yang hendak akan dicapai dalam penelitian ini adalah untuk mengetahui kemampuan motorik kasar anak melalui kegiatan tari kreasi baru (kelas eksperimen) di RA An-Nihayah Bojongranca Kecamatan Cipongkor Kabupaten Bandung Barat, kemampuan motorik kasar anak melalui kegiatan tari daerah (kelas kontrol) di RA An-Nihayah Bojongranca Kecamatan Cipongkor Kabupaten Bandung Barat dan perbedaan kemampuan motorik kasar anak melalui kegiatan tari kreasi baru dengan kegiatan tari daerah di RA AnNihayah Bojongranca Kecamatan Cipongkor Kabupaten Bandung Barat.

\section{Metodologi}

Metode penelitian yang digunakan peneliti dalam penelitiannya menggunakan metode kuasi eksperimen dengan pendekatan kuantitatif, metode penelitian pada dasarnya merupakan cara ilmiah untuk mendapatkan data dengan tujuan dan kegunaan tertentu (Sugiyono, 2012: 2). Metode kuasi eksperimen pada penelitian ini menggunakan desain penelitian nonequivalent control group design (Sugiyono, 2017: 79) pada desain penelitian nonequivalent control group design, penelitian diawali dengan tahap observasi awal pada kemampuan motorik kasar anak (pre test), kemudian diberikan satu kali tindakan (treatment) berupa kegiatan tari kreasi, selanjutnya penelitian diakhiri dengan sebuah observasi akhir (post test) untuk mengukur kemampuan motorik kasar anak dan kemudian dibandingkan dengan keadaan sebelum diberi perlakuan (treatment).

Subjek penelitian ini adalah kelompok B RA An-Nihayah Bojongranca Kecamatan Cipongkor Kabupaten Bandung Barat sebanyak 29 orang siswa. Teknik pengumpulan data dalam penelitian ini menggunakan lembar observasi, unjuk kerja dan dokumentasi. Sumber data penelitian ini menggunakan sumber data populasi dan sampel, sumber data populasi merupakan data yang bersumber dari subjek penelitian yang dapat memberikan informasi terhadap penelitian yang akan dilakukan.

Teknik analisis data dalam penelitian ini menggunakan analisis komparasi, menurut Subana (2000: 167) teknik analisis komparasional merupakan salah satu teknik analisis statistik inferensial yang digunakan untuk menguji hipotesis sebagai upaya penarikan kesimpulan dalam penelitian komparasional. Analisis tersebut digunakan untuk menguji ada tidaknya perbedaan antar variabel yang sedang diteliti, sehingga diperoleh kesimpulan apakah perbedaan itu cukup berarti (signifikan) atau hanya kebetulan. Hal yang perlu 
diperhatikan berkenaan dengan statistik inferensial untuk menguji dua perlakuan yang diperbandingkan adalah persyaratan normalitas data homogenitas varian data.

Uji normalitas diukur dari penilaian observasi dan dilakukan untuk menentukan sekumpulan data berdistribusi normal atau tidak. Menginterpretasikan normalitas data dengan membandingkan harga $\chi^{2}$ bitung dengan $\chi^{2}$ tabel dengan kriteria jika $\chi^{2}$ hitung lebih kecil atau sama dengan $\chi^{2}$ tabel $\left(\chi^{2}\right.$ bitung $\leq \chi^{2}$ tabe $)$, maka data diinterpretasikan normal. Dan Jika $\chi^{2}$ bitung lebih besar $\chi^{2}$ tabel $\left(\chi^{2}\right.$ bitung $>\chi^{2}$ tabel), maka data diinterpretasikan tidak normal.

Uji homogenitas diperlukan untuk mengetahui data yang dibandingkan (dikomparasikan) sejenis (bersifat homogen) atau tidak. Menginterpretasikan homogenitas data dengan cara membandingkan harga $F_{\text {hitung }}$ dengan $F_{\text {tabel }}$ dengan kriteria jika $F_{\text {hitung }}$ lebih kecil dari $F_{\text {tabel }}\left(F_{\text {hitung }} \leq\right.$ atau sama dengan $\left.F_{\text {tabel }}\right)$, maka data memiliki variansi yang homogen. Dan jika $F_{\text {hitung }}$ lebih besar dari $F_{\text {tabel }}\left(F_{\text {hitung }}>F_{\text {tabel }}\right)$, maka data memiliki variansi yang tidak homogen.

Apabila diperoleh hasil kedua variabel berdistribusi normal dan bersifat homogen, maka perhitungan perbedaan rata-rata pada penelitian ini menggunakan Uji t dengan pengujian hipotesis jika $t_{\text {hitung }} \leq t_{\text {tabel }}$ maka Ho diterima dan Ha ditolak, dan jika: $t_{\text {hitung }}>t_{\text {tabel }}$ maka Ho ditolak dan Ha diterima.

\section{Hasil dan Diskusi}

Berdasarkan perhitungan kemampuan motorik kasar anak melalui kegiatan tari kreasi baru (kelas eksperimen) di RA An-Nihayah Bojongranca Kecamatan Cipongkor Kabupaten Bandung Barat saat pre test memiliki nilai tertinggi 67, nilai terendah 44 dan nilai rata-rata 55. Sedangkan pada saat post test memiliki nilai tertinggi 93, nilai terendah 69 dan nilai rata-rata 80 artinya bahwa setelah menggunakan tari kreasi baru, nilai rata-rata kemampuan motorik kasar anak di kelas eksperimen berada pada kategori sangat baik.

Kemampuan motorik kasar anak melalui kegiatan tari daerah (kelas kontrol) di RA An-Nihayah Bojongranca Kecamatan Cipongkor Kabupaten Bandung Barat saat pre test memiliki nilai tertinggi 65 , nilai terendah 42 dan nilai rata-rata 53. Sedangkan post test memiliki nilai tertinggi 85 , nilai terendah 62 dan nilai rata-rata 72 artinya bahwa setelah menggunakan tari daerah, nilai rata-rata kemampuan motorik kasar anak di kelas kontrol berada pada kategori baik. Hasil analisis pre test dan post test kegiatan tari kreasi baru (kelas eksperimen) dan kegiatan tari daerah (kelas kontrol) terlebih dahulu dilakukan uji persyaratan, yaitu uji normalitas dan uji homogenitas yang diuraikan sebagai berikut: 
Berdasarkan perhitungan uji normalitas hasil data pre test dari Kemampuan Motorik Kasar Anak melalui Kegiatan Tari Kreasi Baru (Kelas Eksperimen) diperoleh nila mean $(\bar{x})$ $=55$ dan standar deviasi $(\mathrm{SD})=6,91$. Selain itu, diperoleh $\chi^{2}$ hitung 4,54 dan $\chi_{\text {tabel }}^{2}=7,815$ dengan derajat kebebasan $(\mathrm{db})=5$ pada taraf signifikansi $5 \%$. Karena $\chi^{2}$ hitung $4,54<$ dari $\chi_{\text {tabel }}^{2}=7,815$, maka diinterpretasikan datanya berdistribusi normal. Sedangkan hasil data pre test dari Kemampuan Motorik Kasar Anak melalui Kegiatan Tari Daerah (Kelas kontrol) diperoleh nila mean $(\bar{x})=53$ dan standar deviasi $(\mathrm{SD})=7,12$. Selain itu, diperoleh $\chi^{2}$ hitung 3,27 dan $\chi_{\text {tabel }}^{2}=7,815$ dengan derajat kebebasan $(\mathrm{db})=5$ pada taraf signifikansi $5 \%$. Karena $\chi^{2}$ hitung $3,27<$ dari $\chi_{\text {tabel }}^{2}=7,815$, maka diinterpretasikan datanya berdistribusi normal.

Berdasarkan perhitungan uji normalitas hasil data post test dari Kemampuan Motorik Kasar Anak melalui Kegiatan Tari Kreasi Baru (Kelas Eksperimen) diperoleh nila mean $(\bar{x})$ $=80$ dan standar deviasi $(\mathrm{SD})=6,78$. Selain itu, diperoleh $\chi^{2}$ hitung 1,42 dan $\chi_{\text {tabel }}^{2}=5,991$ dengan derajat kebebasan $(\mathrm{db})=4$ pada taraf signifikansi 5\%. Karena $\chi^{2}$ hitung $1,42<$ dari $\chi_{\text {tabel }}^{2}=5,991$, maka diinterpretasikan datanya berdistribusi normal. Sedangkan hasil data post test dari Kemampuan Motorik Kasar Anak melalui Kegiatan Tari Daerah (Kelas kontrol) diperoleh nila mean $(\bar{x})=72$ dan standar deviasi $(\mathrm{SD})=6,74$. Selain itu, diperoleh $\chi_{\text {hitung }}^{2} 4,91$ dan $\chi_{\text {tabel }}^{2}=7,815$ dengan derajat kebebasan $(\mathrm{db})=5$ pada taraf signifikansi $5 \%$. Karena $\chi^{2}$ hitung $4,91<$ dari $\chi_{\text {tabel }}^{2}=7,815$, maka diinterpretasikan datanya berdistribusi normal.

Berdasarkan perhitungan uji homogenitas hasil data pre test dari Kemampuan Motorik Kasar Anak melalui Kegiatan Tari Kreasi Baru (Kelas Eksperimen) diperoleh nilai varian $(V)=47,70$ dan kegiatan tari daerah (kelas kontrol) diperoleh nilai varian $(V)=50,72$. Selain itu diperoleh $\mathrm{F}_{\text {hitung }} 0,94$ dan $\mathrm{F}_{\text {tabel }} 2,55$ dengan derajat kebebasan $(\mathrm{db})=5$ pada taraf signifikansi 5\%. Karena $\mathrm{F}_{\text {hitung }} 0,94<$ dari $\mathrm{F}_{\text {tabel }}$ 2,55 maka dapat diinterpretasikan bahwa kedua data memiliki varian yang homogen.

Berdasarkan perhitungan uji homogenitas hasil data post test dari Kemampuan Motorik Kasar Anak melalui Kegiatan Tari Kreasi Baru (Kelas Eksperimen) diperoleh nila $\operatorname{varian}(\mathrm{V})=45,95$ dan kegiatan tari daerah (kelas kontrol) diperoleh nilai varian $(\mathrm{V})=$ 45,45. Selain itu diperoleh $F_{\text {hitung }} 1,01$ dan $F_{\text {tabel }} 2,55$ dengan derajat kebebasan $(d b)=5$ pada taraf signifikansi 5\%. Karena $F_{\text {hitung }} 1,01<$ dari $F_{\text {tabel }} 2,55$ maka dapat diinterpretasikan bahwa kedua data memiliki varian yang homogen. 
Hasil uji normalitas dan uji homogenitas kegiatan tari kreasi baru (kelas eksperimen) dan kegiatan tari daerah (kelas kontrol) pre test dan post test, didapatkan bahwa keduanya berdistribusi normal dan bersifat homogen. Maka, dalam perhitungan perbedaan rataratanya menggunakan uji t. Berdasarkan perhitungan uji $\mathrm{t}$ data hasil pre test diperoleh nilai $t_{\text {hitung }}$ sebesar 0,942 dan nilai $t_{\text {tabel }}$ pada taraf signifikansi 5\% sebesar 2,052, atau $t_{\text {hitung }}=0,942$ $<\mathrm{t}_{\text {tabel }}=2$ 2,052. Dengan demikian ho diterima dan ha ditolak dan dapat diinterpretasikan bahwa tidak terdapat berbedaan yang signifikan kemampuan motorik kasar anak antara kelompok yang menggunakan tari kreasi baru dan kelompok yang menggunakan tari daerah. Sedangkan data hasil post test diperoleh nilai thitung sebesar 3,416 dan nilai tabel pada taraf signifikansi $5 \%$ sebesar 2,052, atau $t_{\text {hitung }}=3,416>t_{\text {tabel }}=2,052$. Dengan demikian Ho ditolak dan $\mathrm{Ha}$ diterima dan dapat diinterpretasikan bahwa terdapat perbedaan yang signifikan kemampuan motorik kasar anak antara kelompok yang menggunakan tari kreasi baru dan kelompok yang menggunakan tari daerah.

Pada data hasil pre test diketahui berdistribusi normal dari nilai maksimal 67, nilai minimal sebesar 44 dan nilai rata-rata sebesar 55 . Nilai tersebut berada pada skala 50-59. Artinya realitas kemampuan motorik kasar anak di kelompok B RA An-Nihayah Bojongranca Kecamatan Cipongkor Kabupaten Bandung Barat sebelum perlakuan kegiatan tari kreasi baru (kelas eksperimen) berkualifikasi kurang. Sedangkan data hasil post test juga berdistribusi normal dari nilai maksimal 93, nilai minimal sebesar 69 dan nilai rata-rata sebesar 80. Nilai tersebut berada pada skala 80-100. Artinya realitas kemampuan motorik kasar anak di kelompok B RA An-Nihayah Bojongranca Kecamatan Cipongkor Kabupaten Bandung Barat sesudah perlakuan kegiatan tari kreasi baru (kelas eksperimen) berkualifikasi sangat baik.

Kegiatan tari kreasi baru merupakan pembelajaran yang menyenangkan bagi anak untuk dipelajari, karena tari kreasi baru adalah gerakan tari yang mempunyai koreografi yang berbeda dari tarian yang sudah ada. Hal ini sejalan dengan pendapat Jazuli (2008: 76) bahwa tari kreasi adalah jenis tari yang koreografinya masih bertolak dari tradisi tradisional atau pengembangan dari pola-pola tari yang sudah ada, terbentuknya tari kreasi karena dipengaruhi oleh gaya tari daerah atau negara lain maupun hasil kreativitas penciptanya.

Pelaksanaan kegiatan pembelajaran di pendidikan pra sekolah, kegiatan tari kreasi baru dilaksanakan dalam upaya memperkenalkan atau menjelaskan tentang hal baru dalam menyampaikan pembelajaran yang dapat meningkatkan kemampuan motorik kasar anak. Sebagaimana dikemukakan oleh Campbell (2006: 87) menari merupakan kegiatan untuk 
melatih motorik anak khususnya motorik kasar anak guna mencapai keterampilan, sikap dan apresiatif. Keterampilan didapatkan dari bagaimana anak dapat menggerakkan anggota tubuhnya bak tangan, kepala, kaki, pundak, dan jari-jemari. Melalui tarian, anak mendapatkan kesempatan untuk belajar kreatif mengeluarkan ide gagasannya mempersatukan dan mendemonstrasikan pengetahuannya dengan cara koreografi.

Pada data hasil pre test diketahui berdistribusi normal dari nilai maksimal 65, nilai minimal 42, dan nilai rata-rata sebesar 53. Nilai tersebut berada pada skala 50-59. Artinya realitas kemampuan motorik kasar anak di kelompok B RA An-Nihayah Bojongranca Kecamatan Cipongkor Kabupaten Bandung Barat pada kelas kontrol yang menggunakan kegiatan tari daerah (kelas kontrol) berkualifikasi kurang. Sedangkan data hasil post test juga berdistribusi normal dari nilai maksimal 85, nilai minimal sebesar 62 dan nilai rata-rata sebesar 72. Nilai tersebut berada pada skala 70-79. Artinya realitas kemampuan motorik kasar anak di kelompok B RA An-Nihayah Bojongranca Kecamatan Cipongkor Kabupaten Bandung Barat sesudah perlakuan kegiatan tari daerah (kelas kontrol) berkualifikasi baik.

Kegiatan tari daerah dalam pembelajaran pada pendidikan pra sekolah membuat lebih bermakna, sederhana dan menyenangkan bagi anak, juga merupakan pengalaman kesenian bagi anak. Menurut Jazuli (2008: 139) pembelajaran tari daerah adalah suatu proses usaha yang dilakukan seseorang untuk memperoleh sesuatu perubahan sikap dan tingkah laku sebagai hasil pengalaman berkesenian dan berinteraksi dengan budaya lingkungan untuk mencapai tujuan tertentu.

Berdasarkan hasil uji hipotesis disimpulkan terdapat perbedaan antara kemampuan motorik kasar anak yang menggunakan kegiatan tari kreasi baru (kelas eksperimen) dengan kemampuan motorik kasar anak yang menggunakan kegiatan tari daerah (kelas kontrol) di kelompok B RA An-Nihayah Bojongranca Kecamatan Cipongkor Kabupaten Bandung Barat. Hal ini terbukti melalui uji t yang menunjukkan harga $t_{\text {hitung }}$ sebesar 3,416 dan $t_{\text {tabel }}$ pada taraf signifikansi 5\% sebesar 2,052. Maka $t_{\text {hitung }}=3,416>\mathrm{t}_{\text {tabel }}=2,052$ dan dapat diinterpretasikan hipotesis alternatif $(\mathrm{Ha})$ diterima hipotesis nol $(\mathrm{Ho})$ ditolak. Artinya, terdapat perbedaan yang signifikan antara kemampuan motorik kasar anak yang menggunakan kegiatan tari kreasi baru dan kegiatan tari daerah.

Hal ini sejalan dengan pendapat Mulyani (2016: 60) bahwa tari dapat dikelompokkan menjadi tiga jenis, yaitu jenis tari berdasarkan pola garapan, jenis tari berdasarkan koreografi dan jenis tari berdasarkan tema. Tari daerah merupakan seni tari yang sudah ada 
sejak dulu dan gerakan dalam tari daerah sudah paten, sedangkan tari kreasi baru ialah seni tari yang sudah dikreasikan dan terdapat pembaruan dari tari daerah.

\section{Penutup}

Berdasarkan hasil analisis data tentang kemampuan motorik kasar anak melalui kegiatan tari kreasi baru di kelompok B RA An-Nihayah Bojongranca Kecamatan Cipongkor Kabupaten Bandung Barat dapat disimpulkan bahwa kemampuan motorik kasar anak yang menggunakan kegiatan tari kreasi baru (kelas eksperimen) diperoleh nilai ratarata pre test sebesar 55 dengan kategori kurang, karena berada pada interval 50-59. Sedangkan nilai rata-rata post test sebesar 80 dengan kategori sangat baik, karena berada pada interval 80-100. Sedangkan kemampuan motorik kasar anak yang menggunakan kegiatan tari daerah (kelas kontrol) diperoleh nilai rata-rata pre test sebesar 53 dengan kategori kurang, karena berada pada interval 50-59. Sedangkan nilai rata-rata post test sebesar 72 dengan kategori baik, karena berada pada interval 70-79.

Hasil pengujian data statistik di kelas eksperimen dan di kelas kontrol, menunjukkan bahwa terdapat perbedaan yang signifikansi antara kemampuan motorik kasar anak yang menggunakan kegiatan tari kreasi baru dengan kegiatan tari daerah. Berdasarkan hasil uji $t$ test yang menghasilkan nilai $t_{\text {hitung }}$ sebesar 3,416 dan $t_{\text {tabel }}$ pada taraf signifikansi 5\% sebesar 2,052. Maka $t_{\text {hitung }}=3,416>t_{\text {tabel }}=2,052$. Artinya hipotesis alternatif $(\mathrm{Ha})$ diterima hipotesis nol (Ho) ditolak, dengan kata lain terdapat perbedaan yang signifikan antara kemampuan motorik kasar anak yang menggunakan kegiatan tari kreasi baru dengan kegiatan tari daerah.

\section{Daftar Pustaka}

Campbell, L. D. (2006). Metode Praktis Pembelajaran Berbasis Multiple Intelligences. Depok: Intuisi Press.

Caturwati, E. (2008). Tari di Tatar Sunda.

Decaprio, R. (2013). Aplikasi Pembelajaran Motorik di Sekolah. Jogjakarta: Diva Press.

Jazuli, M. (2008). Pendidikan Seni Budaya Suplemen Pembelajaran Tari. Semarang: Universitas Negeri Semarang.

Merdekawaty, S. R. (2010). Tari Kreasi Baru Nusantara. Bogor: Horizon.

Mulyani, N. (2016). Pendidikan Seni tari Anak Usia Dini. Yogyakarta: Gava Media.

Mursyid. (2015). Pengembangan Pembelajaran PAUD. Bandung: PT Remaja Rosdakarya. 
Rachmi. (2008). Keterampilan Musik dan Tari. Jakarta: Universitas Terbuka.

Saputra, Y., \& Rudyanto. (2005). Pembelajaran Kooperatif untuk Meningkatkan Keterampilan Anak TK. Jakarta: Depdikbud.

Subana. (2000). Statistik Pendidikan. Bandung: Pustaka Setia.

Sugiyono. (2012). Metode Penelitian Kuantitatif Kualitatif dan R\&D. Bandung: Alfabeta.

Sugiyono. (2017). Metode Penelitian Kuantitatif, Kualitatif, dan R\&D . Bandung : Alfabeta.

Suhada, I. (2016). Psikologi Perkembangan. Bandung.

Susanto, A. (2011). Perkembangan Anak Usia Dini Pengantar Dalam berbagai Aspeknya. Jakarta: Kencana Media Grup.

Syah, M. (2003). psikologi Belajar. Jakarta: PT Raja Grafindo.

\section{Biodata Penulis}

Y. Puspa Andriani, lahir di Bandung pada tanggal 07 Juni 1997 dari pasangan Ibu Yuyun dan Bapak Nurzamil, merupakan anak ke empat dari empat bersaudara. Bertempat tinggal di Kp. Bojongranca RT/RW 01/05 Desa Cijenuk Kecamatan Cipongkor Kabupaten Bandung Barat. Saat ini mengajar di RA An-Nihayah Desa Cijenuk Kecamatan Cipongkor Bandung Barat. 